\title{
EFFECTIVE PREPARATION OF NON-LINEAR MATERIAL MODELS USING A PROGRAMMED OPTIMIZATION SCRIPT FOR A NURIMERICAL SIMULATION OF SHEET-METAL PROCESSING
}

\author{
UČINKOVITA PRIPRAVA NELINEARNIH MODELOV MATERIALA \\ S PROGRAMIRANIM OPTIMIZACIJSKIM ZAPISOM ZA \\ NUMERIČNO SIMULACIJO OBDELAVE PLOČEVINE
}

\author{
Miroslav Urbánek, Filip Tikal \\ COMTES FHT a.s., Prumyslova 995, Dobrany, Czech Republic \\ miroslav.urbanek@comtesfht.cz \\ Prejem rokopisa - received: 2013-10-14; sprejem za objavo - accepted for publication: 2014-05-23
}

doi:10.17222/mit.2013.248

\begin{abstract}
Progressive methods and technologies are the key to the dynamic development of the automotive and electrical-engineering industries. The processes in sheet-metal processing have changed fundamentally since the end of the 1990s. Previously, the operations such as cutting, punching holes, etc., were carried out separately on different press machines. These operations can now be integrated into a single tool on one press machine due to the development of progressive tools and, especially, the fine-blanking technology. The result is an already completed component that can be used for the assembly. The development of progressive tools must be supported with the FEM simulations of sheet-metal processing that are dependent on their inputs. Therefore, only a correct material model can be expected to provide the right results.

For the reasons described above, an experimental program dealing with measuring and fitting the data to the models with orthotropic material properties such as rolled sheets was designed and implemented. The aim is to obtain the material models of rolled sheets made of selected aluminum, copper and steel alloys. One of the objectives of the solution is to provide more efficient and more accurate data fitting because the more accurate the input material data are, the more accurate are the simulation results for sheet-metal processing.

The optimization script using the simplex method was made for fitting. The main function of the optimization script is to specify the parameters of the material model iteratively and to compare the simulation results and the mechanical-test results. The script was programmed in the Python environment for the MSC.MARC/MENTAT software using the Johnson-Cook plasticity model. Fitting the data from the pressure tests by Rastegaev at different loading speeds is presented. The difference between the measured and simulated curves is less than $1 \%$.

Keywords: FEM simulation, measurement, compression test, fitting, MSC.MARC, Python
\end{abstract}

Napredne metode in tehnologije so ključne za dinamičen razvoj avtomobilske in elektro- industrije. Procesi preoblikovanja pločevin so se bistveno spremenili od devetdesetih let zadnjega stoletja. Prej so se operacije, kot so rezanje, prebijanje lukenj in podobno, izvajale ločeno na različnih strojih. Zaradi razvoja naprednih orodij in še posebej tehnologije precizijskega štancanja se te operacije lahko združi v enem orodju na enem stroju. Rezultat je kompletna komponenta, ki je primerna za vgradnjo. Razvoj naprednih orodij mora biti podprt s FEM-simulacijami obdelave pločevine, kar je odvisno od vhodnih veličin. Zato samo pravilen model materiala lahko zagotavlja prave rezultate.

Iz navedenih razlogov je bil postavljen in uporabljen eksperimentalni program, ki obravnava merjenje in ujemanje podatkov za modele z ortotropnimi lastnostmi materiala, kot je valjana pločevina. Namen je dobiti modele materiala valjane pločevine za izbrane aluminijeve in bakrove zlitine ter jekla. Eden od ciljev je zagotoviti bolj učinkovito in bolj zanesljivo pridobivanje podatkov, kajti čim bolj zanesljivi so vhodni podatki materiala, bolj natančni so rezultati simulacije pri obdelovanju pločevine. Za prilagajanje je bila uporabljena optimizacija zapisa $\mathrm{z}$ uporabo simpleksne metode. Glavna vloga optimizacijskega zapisa je iterativna opredelitev parametrov modela materiala in primerjava rezultatov simulacije z rezultati mehanskih preizkusov. Zapis je bil programiran v okolju Python za programsko opremo MSC.MARC/MENTAT z uporabo Johnson-Cookovega modela plastičnosti. Predstavljeno je ujemanje podatkov iz Rastegaevega tlačnega preizkusa pri različnih hitrostih obremenjevanja. Razlika med izmerjenimi in simuliranimi krivuljami je manj kot $1 \%$.

Ključne besede: FEM-simulacija, merjenje, tlačni preizkus, ujemanje, MSC.MARC, Python

\section{INTRODUCTION}

The economic crisis dragging on since 2007 exerts an increasing pressure on the suppliers of the components for the automotive and electrotechnical industries. In general, the aim is to maintain a high quality of the components while reducing the inputs. The aim can only be achieved by deploying more advanced and less costly technologies that offer a higher efficiency. Such were also the reasons leading to the creation of the international EUREKA project aimed primarily at replacing the costly machining processes with lower-cost and more advanced manufacturing processes for making flat products. The existing fine-blanking process delivers precision sheet products with the tolerances of IT8-IT9. Fine-blanking combined with bulk forming (chamfering, stepping down and other operations) of metal-sheet components represents an advanced manufacturing approach. The production time for a part made with this technique is reduced to seconds, while the required accuracy and quality of the functional surfaces are maintained. A typical example of a flat product with 


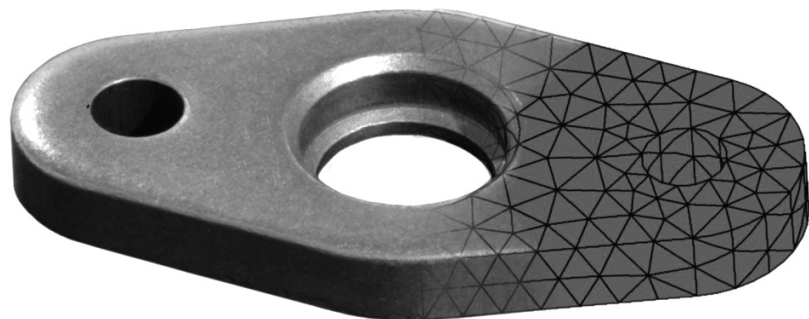

Figure 1: Example of a flat product with spatial features Slika 1: Primer ploščatega izdelka s prostorsko mrežo

spatial features, such as a cylindrical recess, is shown in Figure 1. ${ }^{1-3}$

Today's professional literature around the world describes various approaches to measuring material characteristics. They concern not only elastic-plastic materials, such as metal alloys, but also viscoelastic materials, such as rubber. Elastic-plastic models typically rely on a suitable form of the Johnson-Cook flow-stress model, defined with Equation (1) representing the stress-strain curve. This model can provide a comprehensive description of a material at various strain rates and temperatures. ${ }^{4,5}$

Previously, we performed fitting by hand when individual states were fitted, which provided us with more accurate results for a single load condition (a single temperature or strain rate), but for a comprehensive assessment of material properties this method is insufficient and also time-consuming. In addition, the dependence of the material behavior on the states was not respected. Specifically, a material stiffens more during faster loading and it is more pliable at a higher temperature.

\section{PREPARATION OF THE MATERIAL MODELS}

Material characteristics are measured using standardized and other physical methods with the test machines that record the force and time or displacement (the plunger displacement). The force-versus-displacement plots are evaluated and transformed by means of formulas to obtain the required quantities, such as stress, strain, elongation and others.

In order to obtain the correct values of material characteristics, it is advisable to perform a test simulating the actual manufacturing process in a simplified form: on a smaller scale, for instance. There are various factors having an impact on the quality of the measurement record, such as the measurement method, the test configuration, the quality of the sensors, the machine stiffness, the loading velocity and others. ${ }^{1-3}$

In the present project, a rapid and effective datafitting procedure for various physical measurements was developed and implemented. Data fitting is in essence a fine tuning of the material-property data obtained with the mechanical tests. Data fitting comprises four main steps. The first one involves a physical measurement and an evaluation. The next step is smoothing where a smooth continuous polynomial curve is fitted to the jagged test plot. In the third step, parameters are estimated with an approximation. The last step consists of a numerical analysis under the conditions identical to those of the physical measurement. Using a pre-programmed optimization script, the constants for the material model are sought.

In the following sections, these steps for an effective material-data preparation will be described in greater detail. For most of the steps, the scripts were developed in the user-friendly Python environment. Most scripts were written with the aid of open source libraries facilitating the preparation.

The term physical measurement can denote a standard compression or tension test. The COMTES FHT a. s. company generally deals with standard and non-standard measurements of specimens and functional items. For this reason, the optimization script used for finding the parameters of a material model should be versatile enough to apply to most of the measurements.

The measurement data is evaluated and corrected for further processing, if required. In general, smooth curves are easier to work with, especially when using mathematical algorithms. The smoothing can be modified with a user-defined parameter, which alters the shape of the resulting curve. The time required is very short: at the order of seconds.

Using the corrected curve obtained from the physical measurement under the quasi-static conditions at room temperature, some parameters can be estimated with the aid of the generally known formulas based on the volume conservation, the yield strength and the engineering strain. ${ }^{2,3,5}$

In addition, these estimated parameters are used as the input parameters for the optimization script controlling the numerical simulation. The optimization script is iterative (Figure 2) seeking the constants for a general material model according to Johnson-Cook. The model is defined with an equation comprising five constants derived from the material properties. Other terms of the

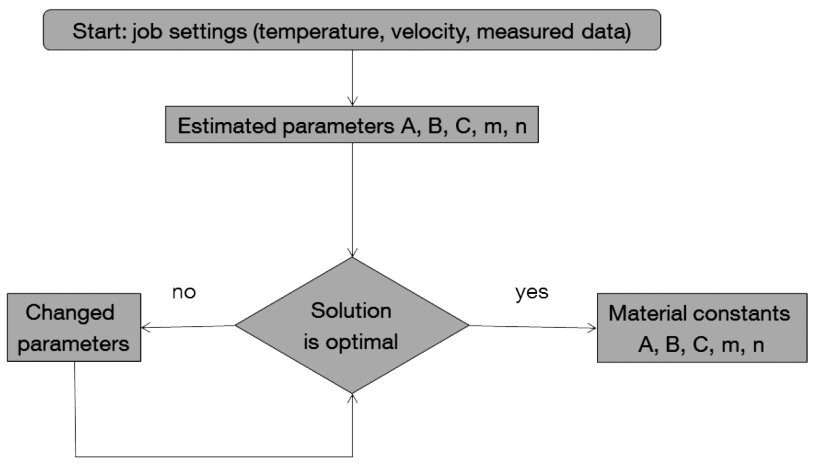

Figure 2: Simplex algorithm using the Johnson-Cook model of flow stress

Slika 2: Algoritem simpleks, ki uporablja Johnson-Cookov model za napetost tečenja 
equation (Equation (1)) depend on the boundary and initial conditions of the process (temperatures, strain rates) and their meanings are described below. In the previous step, constants $A, B$ and $n$ of the Johnson-Cook equation, which depend on the strain hardening and yield strength, were estimated. Generally, the equations of the Johnson-Cook model describe the material in all the states. The state change is defined with the value of the relevant constant. The $A, B, C, m$ and $n$ constants determine the material state at all the temperatures and rates:

$\sigma_{v}=\left(A+B \cdot \varepsilon_{\mathrm{p}}^{n}\right) \cdot\left(1+C \cdot \ln \left(\frac{\dot{\varepsilon}}{\dot{\varepsilon}_{0}}\right)\right) \cdot\left(1-\left(\frac{T-T_{\text {room }}}{T_{\text {melt }}-T_{\text {room }}}\right)^{m}\right)(1)$

The Johnson-Cook model represents the flow-stress values describing the material behaviour under deformation. Equation (1) consists of a product of the terms governed by the plastic strain, the strain rate and the temperature. The first term $\left(A+B \cdot \varepsilon_{\mathrm{p}}^{n}\right)$ describes the beginning of the plastic-flow segment of the stress-strain curve where $A$ is the yield strength (MPa). The plasticflow segment depends on the $B$ strain-hardening modulus (MPa), the plastic strain $\varepsilon_{\mathrm{p}}$ and the strain exponent $n$. The second term $\left(1+C \cdot \ln \left(\dot{\varepsilon} / \dot{\varepsilon}_{0}\right)\right)$ consists of a dimensionless coefficient of sensitivity to strain rate $C$, the strain-rate ration logarithm $\dot{\varepsilon}\left(\mathrm{s}^{-1}\right)$ and the reference strain rate $\varepsilon_{0}\left(\mathrm{~s}^{-1}\right)$, which is normally taken as $\varepsilon_{0}=1 \mathrm{~s}^{-1}$. The last term of the equation $\left\{1-\left(\frac{T-T_{\text {room }}}{T_{\text {melt }}-T_{\text {room }}}\right)^{m}\right\}$ which describes the effect of the temperature consists of a ratio of two temperature differences where individual terms denote the current temperature $T\left({ }^{\circ} \mathrm{C}\right)$, the room temperature $T_{\text {room }}\left({ }^{\circ} \mathrm{C}\right)$ and the melting temperature $T_{\text {melt }}$ $\left({ }^{\circ} \mathrm{C}\right) .{ }^{6,7}$

The optimization script relies on the simplex algorithm, which is a linear iterative method. The outcome of the simplex algorithm is the value of the objective function. The values of the previous and the current steps are compared. The objective function is the evaluation

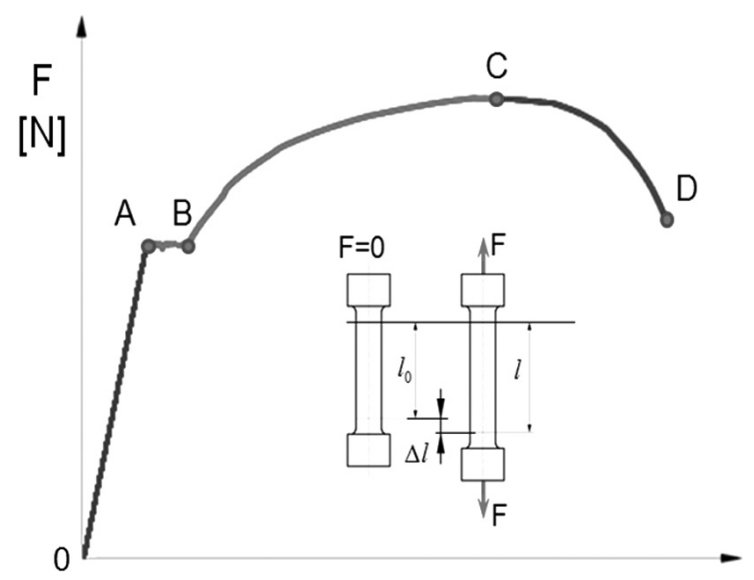

Figure 3: Graph of the tensile test

Slika 3: Diagram nateznega preizkusa criterion for the optimization method that seeks the minimum value of the function. With the single-digit values (e.g., 5), the curves are virtually identical. By contrast, at higher values (such as 120), there are differences between them, leading to inaccurate results.

The optimization involves comparing the measured data (or smoothed data) with the results of the numerical simulation (Figure 2). COMTES FHT a. s. uses the software solutions provided by MSC Software, which has been developing the finite-element-method-based software for numerical simulations for 50 years. The script relies on MSC.MENTAT as the pre- and post-processor and on MSC.MARC as the solver. The latter was developed for strongly non-linear analyses. ${ }^{6-8}$

It is important to bear in mind that errors occur in both the physical measurement and the numerical simulation. In addition, when the material-model constants are corrected with regard to multiple measurements under varying conditions, the results cannot be identical for all the states.

\section{DESCRIPTION OF THE MATERIAL}

The complex behaviour of the materials can be described in a simplified manner with a tension-test curve (Figure 3) which, generally, comprises three segments. The first linear segment of the tension-test plot is described with Hooke's law (from 0 to A) given by the Poisson's ratio and Young's modulus. In the second segment of the plot (from A to C), the plastic deformation begins to occur at the yield stress. Beyond that point, the plastic flow continues and the material strain hardens up to the ultimate tensile strength. This red segment is described with plasticity models. In this case, it is the Johnson-Cook model. Once the ultimate strength is exceeded, the plasticity of the material is used up and cracks develop, leading to a destruction of the test specimen (from $\mathrm{C}$ to $\mathrm{D}$ ). The last segment of the curve is modelled using damage criteria which describe the condition of the material through the widely known Cockroft-Latham model:

$$
\int \frac{\sigma_{\max }}{\bar{\sigma}} \dot{\bar{\varepsilon}} \mathrm{d} t \geq C
$$

\section{COMPRESSION TEST}

In a demonstration of the application, the Rastegaev compression test (Figure 4) is described as a test suitable from multiple standpoints. First, the test configuration allows the data to be measured correctly without any friction effects. Furthermore, the test can be simplified for the numerical simulation to a $2 \mathrm{D}$ axially symmetric problem (Figure 5), due to the axially symmetric test specimen. This type of analysis provides an excellent description of the specimen throughout the process using a relatively small number of elements. Thanks to the small number of elements, short computation times are 


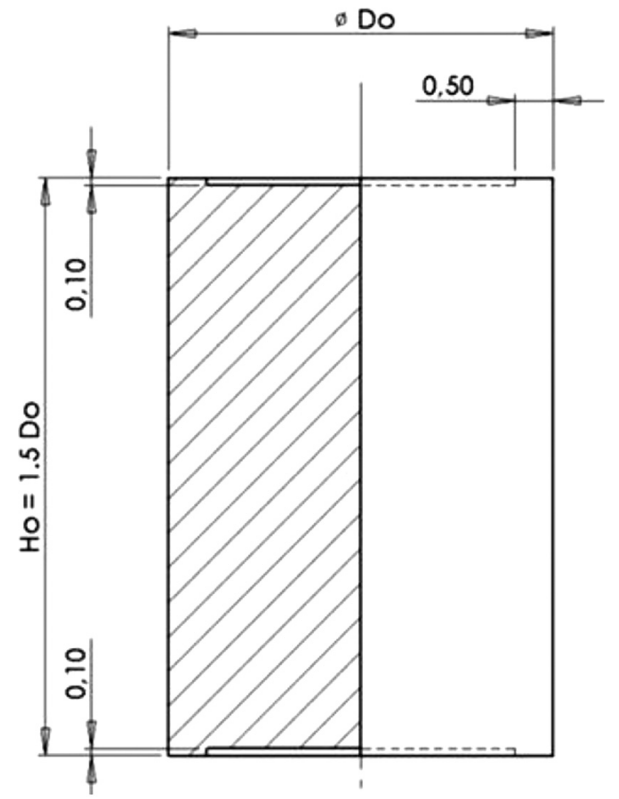

Figure 4: Specimen for the Rastegaev compression test Slika 4: Vzorec za Rastegaevov tlačni preizkus

achieved. With the optimization of the material parameters for the compression test, a single iteration step of the optimization script takes approximately $10 \mathrm{~s}$, of which the calculation itself takes about $6 \mathrm{~s}$. The remaining time is used for setting up and evaluating the calculation. These times are, understandably, dependent on the computer-workstation hardware. With the above steps, this short data fitting becomes a comparatively rapid procedure. The optimization iteration takes place involving multiple measurement-data sets in order to find the correct material constants. Naturally, the more measurement-data sets are available for various temperatures and speeds, the easier it is to find the material-model constants.
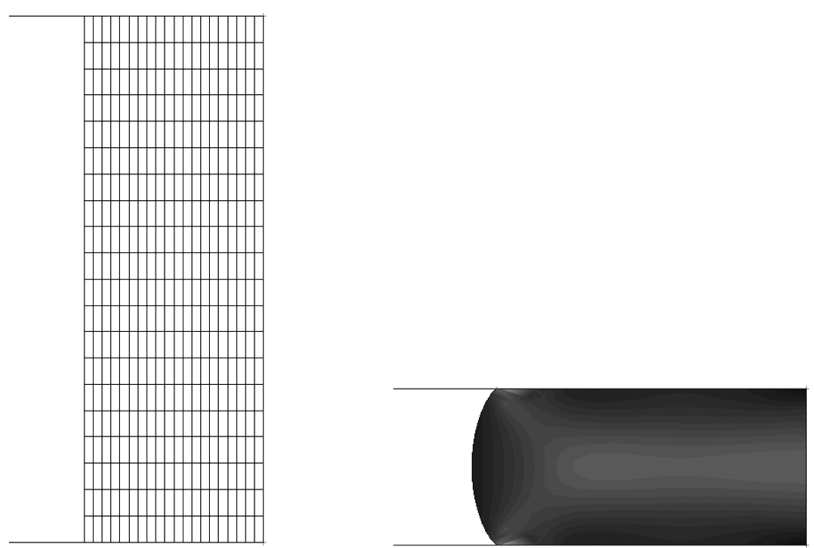

Figure 5: Axisymmetric model of the compression test in MSC.MARC/MENTAT in the initial and deformed states

Slika 5: Osnosimetrični model tlačnega preizkusa v MSC.MARC/ MENTAT začetnem in deformiranem stanju

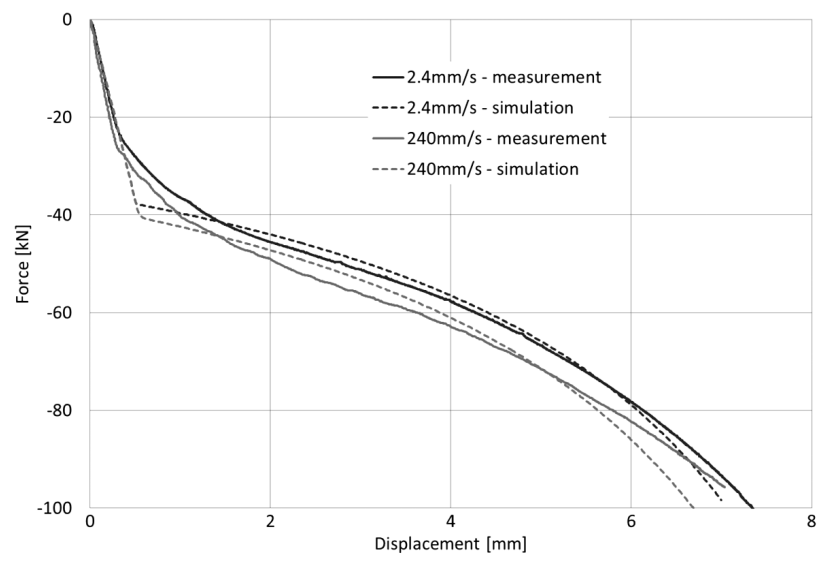

Figure 6: Comparison of the numerical simulation and physical measurements

Slika 6: Primerjava numerične simulacije in fizikalnih meritev

The method was applied to fitting the measurement data for the $16 \mathrm{MnCr} 5$ manganese steel. The specimens of this material were taken along the forming direction and loaded at the rates of $2.4 \mathrm{~m} / \mathrm{s}$ and $240 \mathrm{~mm} / \mathrm{s}$ at room temperature. The plot (Figure 6) contains solid lines representing the measured curves and dash-and-dot lines showing the simulation curves for identical boundary conditions. Upon fine tuning, the Johnson-Cook model parameters were as follows: $A=554 \mathrm{MPa}, B=198 \mathrm{MPa}$, $n=0.00035, C=0.0215$ and $m=0.0335$. Although the specimens were kept at room temperature, the effect of the temperature on the specimens this small $\left(D_{0}=8 \mathrm{~mm}\right.$ and height $H_{0}=11.5 \mathrm{~mm}$ ) and loaded at high strain rates is not negligible.

\section{CONCLUSION}

Using the above-demonstrated data-fitting procedure for obtaining the material constants, the material models can be fine-tuned quickly and effectively. A smart choice of the test specimens simplifies the numerical simulation and allows the entire data-fitting process to be automated. Thanks to the MSC.MARC/MENTAT environment, the optimization script was developed in the PYTHON language and the curve-smoothing tools, so that the material data of the Johnson-Cook flow-stress model can be used in other FEM-based programs as well.

The objective of the solution developed herein was to obtain as accurate the material data as possible for constructing a numerical model of shearing and forming flat products with spatial features for orthotropic materials.

The comparison graph (Figure 6) suggests that the material model is suitable for characterizing the spatial features in forming a flat product.

The main result is the working optimization script for fitting, which efficiently searches for the material-model constants that will subsequently be used for the simulations of cold forming. With precise results, it is possible 
to better describe the process of forming and to optimize it not only in terms of the material flow, but also in terms of the tools stress. The next step will be the preparation of a script for fitting for various mechanical tests and material-seeking models using other measurement types, such as tensile, compressive or shear tests.

\section{Acknowledgement}

The authors of this paper gratefully acknowledge the support from the EUREKA LF12009 project: Research and Development of a New Technology of Cold Precision Forming as a Replacement for the Cutting Operations.

\section{REFERENCES}

${ }^{1}$ M. Urbánek, F. Tikal, Určení koeficientů materiálových modelů pro tvářecí procesy, Hutnické listy, LXVI (2013) 4, 71

${ }^{2}$ M. Španiel, A. Prantl, J. Džugan, J. Růžička, M. Moravec, J. Kuželka, Calibration of fracture locus in scope of uncoupled elastic-plastic-ductile fracture material models, Advances in Engineering Software, 72 (2014), 95-108, doi:10.1016/j.advengsoft.2013. 05.007

${ }^{3}$ P. Kubík, F. Šebek, J. Petruška, J. Hůlka, J. Růžička, M. Španiel, J. Džugan, A. Prantl, Calibration of Selected Ductile Fracture Criteria Using Two Types of Specimens, Key Engineering Materials, 592-593 (2013), 258-261, doi:10.4028/www.scientific.net/KEM. 592-593.258

${ }^{4}$ R. A. Smidt, F. Bitzer, P. Höfer, M. Hellmann, B. Reh, P. Rademacher, H. Hoffman, Cold Forming and Fineblanking, Druckhaus Thomas Mützen, Germany 2007

${ }^{5}$ J. Dzugan, M. Spaniel, P. Konopík, J. Ruzicka, J. Kuzelka, Identification of Ductile Damage Parameters for Austenitic Steel, World Academy of Science, Engineering and Technology, 6 (2012) 5, 1291-1296

${ }^{6}$ J. Džugan, M. Zemko, Input data influence on FEM simulation of steam turbine blades materials hot forming, Materials Science Forum, 773-774 (2013), 79-88, doi:10.4028/www.scientific.net/ msf.773-774.79

${ }^{7}$ Marc ${ }^{\circledR} 2012$, Volume A, Theory and User Information

${ }^{8}$ Simplexová metoda, website, www.algoritmy.net/article/1416/Simplexova-metoda, accessed 14 Oct. 2013 